Tersedia online di: http://ejournal-balitbang.kkp.go.id/index.php/jra

\title{
KARAKTERISTIK FENOTIPE DAN GENOTIPE LIMA STRAIN IKAN MAS DI JAWA BARAT DAN BANTEN
}

\author{
Didik Ariyanto ${ }^{* *}$, Odang Carman ${ }^{* *}$, Dinar Tri Soelistyowati*), Muhammad Zairin Jr." ${ }^{* *}$, dan \\ Muhamad Syukur**) \\ *) Balai Riset Pemuliaan Ikan \\ Jl. Raya 2 Sukamandi Pantura, Patokbeusi, Subang 41263 \\ *) Departemen Budidaya Perairan, Fakultas Perikanan dan IImu Kelautan, Institut Pertanian Bogor \\ Kampus IPB Darmaga, Jl. Agatis, Babakan, Dramaga, Bogor, Jawa Barat 16680 \\ ***) Departemen Agronomi dan Hortikulutura, Fakultas Pertanian, Institut Pertanian Bogor \\ Kampus IPB Darmaga, Jl. Meranti, Babakan, Dramaga, Bogor, Jawa Barat 16680
}

(Naskah diterima: 11 Mei 2018; Revisi final: 8 Agustus 2018; Disetujui publikasi: 8 Agustus 2018)

\begin{abstract}
ABSTRAK
Langkah awal program pemuliaan adalah koleksi dan pengenalan karakter materi pemuliaan tersebut. Hasil karakterisasi digunakan sebagai dasar pertimbangan metode pelaksanaan program pemuliaan yang akan dilakukan. Koleksi material genetik untuk program pemuliaan ikan mas menghasilkan lima strain yang dominan dibudidaya di wilayah Jawa Barat dan Banten, yakni strain Rajadanu, Sutisna, Majalaya, Wildan, dan Sinyonya. Pengenalan karakter material genetik ikan mas hasil koleksi dilakukan melalui dua pendekatan, yaitu fenotipe menggunakan metode truss morfometrik dan genotipe menggunakan metode mikrosatelit DNA. Hasil analisis menunjukkan bahwa variasi keragaan fenotipe kelima strain ikan mas relatif sesuai dengan variasi keragaan genotipenya. Selain mengelompokkan antar strain, hasil analisis genotipe juga menunjukkan bahwa tingkat keragaman genetik kelima strain ikan mas yang diindikasikan dengan nilai heterozigositas $(\mathrm{Ho})$ relatif rendah, yaitu berkisar antara 0,08-0,20 dengan jarak genetik antar strain berada dalam kisaran 0,420-0,582.
\end{abstract}

KATA KUNCl: $\quad$ karakterisasi; truss morfometrik; mikrosatelit; ikan mas

ABTRACT: Phenotype and genotype characteristics of five strains of common carp from West Java and Banten Province, Indonesia. By: Didik Ariyanto, Odang Carman, Dinar Tri Soelistyowati, Muhammad Zairin Jr., and Muhamad Syukur

The first step in a fish breeding program is the collection and characterization of the breeding subject. The results of characterization areused as a baseline to select suitable potential methods used in the breeding program. The samples of genetic materials of five strains of common carp (Rajadanu, Sutisna, Majalaya, Wildan, and Sinyonya) were obtained from West Java and Banten Province. The characterization of collected genetic materials of the common carp species followed the phenotype and genotype approaches. Phenotypic characterization used truss morphometric method while genotype characterization applied DNA microsatellite method. The results showed that the phenotypic variation of the common carp had a close fit with its genotypic variation. In addition, the genotype analysisalso showed that the genetic diversity level of the strains was relatively low indicated by the narrow ranges of heterozygosity values $(\mathrm{Ho})$ (0.08-0.20) and genetic distance among strains (0.420-0.582).

KEYWORDS: characterization; truss morphometric; microsatellite; common carp

\section{PENDAHULUAN}

Pengembangan budidaya ikan mas di Indonesia mengalami kendala yang cukup serius. Hal ini ditandai

\# Korespondensi: Balai Riset Pemuliaan Ikan. Jl. Raya 2

Sukamandi Pantura, Patokbeusi, Subang 41263, Indonesia.

Tel. + 62217520482

E-mail: didik_ski@yahoo.com dengan penurunan jumlah produksi ikan mas budidaya sejak sekitar tahun 2003 (Rukmono, 2005). Penurunan angka produksi ikan mas disebabkan oleh adanya serangan penyakit dan penurunan laju pertumbuhan benih. Ketidakmampuan benih menghadapi serangan penyakit, serta penurunan laju pertumbuhan ini diduga karena benih telah mengalami penurunan kualitas genetik. Penurunan kualitas genetik benih ikan mas 
budidaya diduga kuat terkait dengan kesalahan manajemen perbenihan pada tingkat pembenih (Subagyo et al., 2000). Kondisi tersebut menuntut segera dilakukannya perbaikan mutu genetik (pemuliaan) benih ikan mas budidaya.

Dalam rangka kegiatan pemuliaan, langkah pertama yang perlu dilakukan adalah pengenalan terhadap karakter plasma nutfah. Pengenalan karakter dapat dilakukan melalui dua pendekatan, yaitu secara fenotipe dan genotipe. Karakterisasi fenotipe yang mempunyai akurasi hasil cukup tinggi adalah menggunakan metode truss morphometric. Pengukuran karakter morfometrik menggunakan pola truss memberikan gambaran bentuk tubuh yang lebih menyeluruh. Metode ini menghasilkan karakter geometrik bentuk tubuh secara lebih sistematis dan menunjukkan peningkatan kemampuan dalam mengidentifikasi perbedaan-perbedaan bentuk tubuh pada ikan. Metode truss morfometrik banyak digunakan untuk mengidentifikasi perbedaan bentuk tubuh ikan seperti pada ikan nila (Velasco et al., 1996), ikan salmon (Swain et al., 1991), ikan mackerel (Jayasankaret al., 2004), dan ikan mas (Imron, 2000).

Dalam banyak kasus, karakter fenotipe suatu populasi dipengaruhi oleh kondisi lingkungan tempat populasi tersebut berkembang. Dalam rangka mengonfirmasi keragaman karakter fenotipe, dikembangkan metode karakterisasi pada tingkat genotipe. Karakterisasi genotipe molekuler yang banyak digunakan sebagai analisis pembeda antar populasi plasma nutfah adalah analisis DNA mikrosatelit (Takezaki \& Nei, 1996). DNA mikrosatelit merupakan suatu urutan basa N pendek pada DNA, biasanya terdiri atas dua sampai lima basa $\mathrm{N}$ (disebut sebagai motif), yang berulang-ulang tanpa tersela. Panjang pengulangan ini bervariasi tergantung individu/varietas dan diwariskan kepada generasi berikutnya. Mutasi dapat terjadi terhadap banyaknya pengulangan ini sehingga muncul variasi panjang pengulangan di dalam individu-individu dalam suatu spesies. Variasi ini membuat mikrosatelit dapat digunakan sebagai penanda genetik. Penerapan metode mikrosatelit untuk mengkarakterisasi spesies-spesies ikan telah dilakukan antara lain pada ikan rainbow trout (Herbinger et al., 1995), ikan nila (Romana-Eguia et al., 2004), dan ikan mas (Yue et al., 2004; Thai et al., 2007; Hulak et al., 2010).

Penelitian ini bertujuan mengidentifikasi karakter fenotipe dan genotipe lima strain ikan mas di Jawa Barat dan Banten, yaitu strain Rajadanu, Sutisna, Majalaya, Wildan, dan Sinyonya. Hasil penelitian ini digunakan sebagai dasar pertimbangan pelaksanaan kegiatan pemuliaan ikan mas selanjutnya.

\section{BAHAN DAN METODE}

\section{Populasi Ikan Mas}

Bahan penelitian adalah lima strain ikan mas milik Balai Penelitian Pemuliaan Ikan, Sukamandi yang dikoleksi tahun 2010-2012. Populasi ikan mas terdiri atas strain Rajadanu dan Sutisna dari Kabupaten Kuningan (Jawa Barat), strain Majalaya dari Kabupaten Bandung (Jawa Barat), strain Wildan dari Kabupaten Cianjur (Jawa Barat), dan strain Sinyonya dari Kabupaten Pandeglang (Banten).

\section{Karakterisasi Fenotipe}

Analisis keragaman karakter fenotipe dilakukan menggunakan metode truss morphometric. Benih sampel diambil dari hasil pemijahan tiga pasang induk dari masing-masing strain, berukuran 25-50 g per ekor. Jumlah sampel sebanyak 50 ekor/strain, terdiri atas 25 ekor jantan dan 25 ekor betina. Pengambilan titiktitik patokan yang jelas, konsisten, dan homolog dari satu sampel ke sampel lain dipilih di sekitar garis bentuk (outline) tubuh ikan mengikuti Nugroho et al. (1991) dan Imron et al. (2000). Pengukuran jarak antara titik-titik patokan dilakukan menggunakan mistar ukur dengan ketelitian $0,5 \mathrm{~mm}$.

\section{Karakterisasi Genotipe}

Karakterisasi genotipe dilakukan menggunakan metode DNA mikrosatelit. Bahan yang digunakan adalah potongan sirip induk ikan mas hasil koleksi, sebanyak 10 ekor/strain. Secara umum, analisis DNA mikrosatelit terdiri atas tahap ekstraksi DNA, amplifikasi DNA dalam mesin PCR, elektroforesis, dan analisis fragmen DNA. Karakteristik genotipe dianalisis menggunakan lima lokus mikrosatelit, yaitu M FW -6, MFW-7, MFW-9, MFW-13, dan MFW-16 (Yue et al., 2004; Thai et al., 2007).

\section{Analisis Data}

Data fenotipe dianalisis menggunakan analisis komponen utama (Principal Componen Analysis/PCA) sebagai pembeda bentuk tubuh antar strain. Analisis ragam multivariasi (Amova) dilakukan antar populasi jantan dan betina untuk mengetahui kemungkinan adanya dimorfisme seksual. Analisis komponen utama dilakukan pada populasi jantan dan betina secara terpisah jika secara nyata terdapat perbedaan antara populasi jantan dan betina. Analisis data gabungan populasi jantan dan betina dilakukan sebagai pembanding. Analisis komponen utama dilakukan mengikuti prosedur Strauss \& Bond (1990) dan Edge et al. (1991). Analisis data dilakukan menggunakan program SPSS 16.0. 
Parameter genotipe meliputi jumlah alel setiap lokus, frekuensi alel, diversitas gen, heteroziogositas, polimorfisme dan jarak genetik dianalisis menggunakan program Power Maker V3.25. Visualisasi hubungan antar strain dalam bentuk dendrogram dilakukan menggunakan metode UPGM A (Unweighted Pair Group Method with Aritmatic Mean).

\section{HASIL DAN BAHASAN}

\section{Karakteristik Fenotipe}

Analisis ragam multivariasi antara populasi jantan dan betina memberikan nilai $F_{\text {hitung }}=1,663$ dan $P=$ 0,038 . Hasil ini mengindikasikan adanya dimorfisme seksual pada bentuk tubuh ikan mas, sehingga analisis lanjutan menggunakan analisis komponen utama dilakukan pada masing-masing jenis kelamin. Analisis gabungan kedua jenis kelamin dilakukan sebagai pembanding. Hasil anal isis komponen utama populasi jantan, betina, serta gabungan disajikan pada Tabel 1 . Analisis pengelompokan bentuk tubuh berdasarkan analisis komponen utama disajikan dalam bentuk diagram pencar (scatter plot) pada Gambar 1, dan analisis gerombol (cluster analysis) berdasarkan kemiripan bentuk tubuh antar strain ikan mas disajikan dalam bentuk dendrogram pada Gambar 2.

Tiga komponen utama yang dibangun berdasarkan nilai-nilai karakter truss dalam analisis morfometrik menunjukkan keragaman bentuk tubuh populasi ikan mas hingga 58,9\% pada populasi jantan; 52,4\% pada populasi betina; dan $52,9 \%$ pada populasi gabungan (Tabel 1). Hal ini menunjukkan bahwa metode yang digunakan pada penelitian ini relatif baik dalam membedakan bentuk tubuh antar strain ikan mas. Hasil analisis komponen utama pada PC-1 dan PC-2 populasi jantan menunjukkan bahwa strain Sutisna mempunyai kemiripan tinggi dengan strain Sinyonya sedangkan strain Rajadanu mempunyai kemiripan dengan strain Majalaya (Gambar 1A). Analisis pada populasi betina menunjukkan pola yang hampir sama, yaitu strain Sutisna mempunyai kemiripan tinggi dengan strain Sinyonya, tetapi bentuk tubuh strain Rajadanu berbeda dengan strain Majalaya (Gambar 1B). Hasil analisis populasi gabungan mendukung hasil analisis pada kedua populasi di atas yang menunjukkan bahwa strain Sutisna mempunyai kemiripan yang tinggi dengan strain Sinyonya. Analisis data gabungan juga menunjukkan bahwa bentuk tubuh yang paling berbeda adalah antara strain Rajadanu dengan strain M ajalaya. $\mathrm{Hal}$ ini diindikasikan dengan daerah sebaran individu yang berhimpitan antara kedua strain tersebut relatif sedikit (Gambar 1C). Berdasarkan Tabel 1, karakter truss yang secara nyata berkontribusi terhadap pembedaan antar strain tersebut adalah A-3, A-4, A-6, B-3, B-4, B-5, C-4, C-5, dan D-3. Hasil ini menunjukkan bahwa perbedaan bentuk tubuh antar strain ikan mas merata pada semua bagian tubuh, mulai dari bentuk kepala, badan bagian depan dan belakang hingga batang ekor.

Hasil analisis gerombol berdasarkan tingkat kemiripan bentuk tubuh antar strain ikan mas menunjukkan bahwa kelima strain ikan mas dalam penelitian ini terbagi menjadi tiga kelompok besar, yaitu strain Sinyonya, Sutisna, dan Wildan dalam satu kelompok sedangkan strain Rajadanu dan Majalaya menjadi kelompok-kelompok yang berbeda (Gambar 2). Hasil ini mendukung hasil analisis sebelumnya yang menunjukkan bahwa strain Sutisna dan Sinyonya mempunyai kemiripan bentuk tubuh yang tinggi, sedangkan bentuk tubuh strain Rajadanu dan Majalaya saling berbeda.
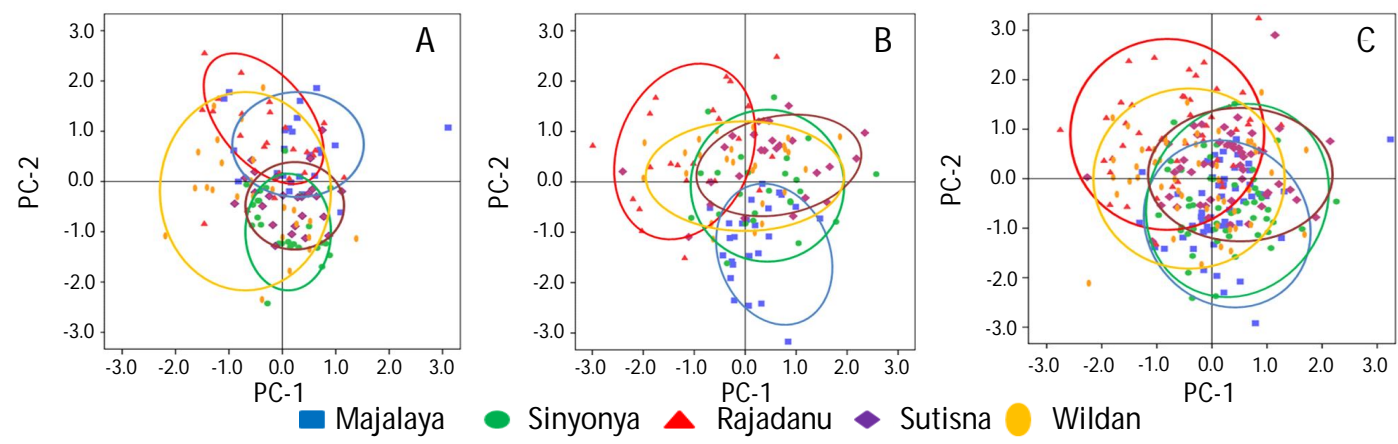

Gambar 1. Diagram pencar komponen utama 1 dan 2 (PC-1, PC-2) pada populasi ikan mas jantan $(A)$, betina $(B)$, dan gabungan $(C)$ menggunakan 21 jarak truss.

Figure 1. Scatter plot for the first and second $P C$ in male (A), female (B), and combination (C) population of common carp using 21 truss characters. 
Rescaled distance cluster combine

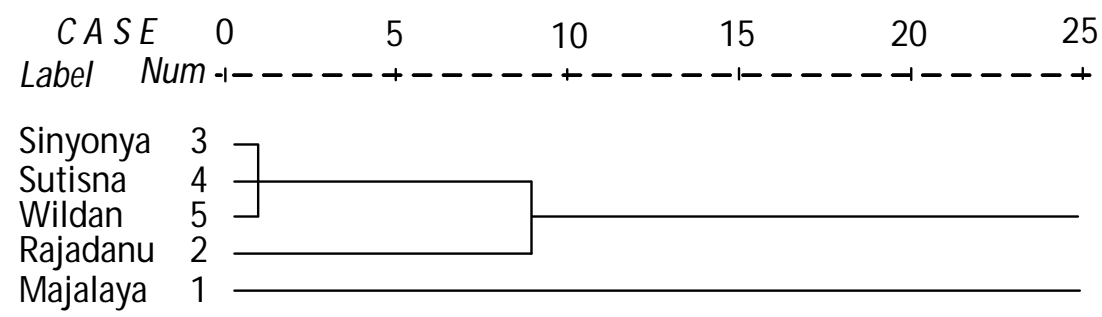

Gambar 2. Dendrogram yang menunjukkan tingkat kemiripan morfologi lima strain ikan mas.

Figure 2. Dendrogram showing the morphological similarity among five strains of common carp.

Secara umum, penampilan fenotipe populasi ditentukan oleh keragaan genetik dan dipengaruhi oleh kondisi lingkungan. Pada populasi ikan mas, pengaruh kondisi lingkungan terhadap keragaman morfologi populasi tersebut sangat besar (Wang \& Li, 2007; Ninh et al., 2011). Hasil penelitian yang dilakukan oleh Matricia (1990), Hardjamulia et al. (1996), dan Imron et al. (2000) pada populasi ikan mas menunjukkan bahwa strain Rajadanu dan Sutisna mempunyai bentuk tubuh yang relatif sama. Hal ini diduga karena kedua strain tersebut dikembangkan di daerah dengan kondisi geografis dan agro-klimatologis yang sama, yaitu di daerah Kuningan, Jawa Barat. Imron et al. (2000) juga memperoleh hasil bahwa bentuk tubuh ikan mas strain Majalaya dari daerah Bandung mempunyai kemiripan tinggi dengan strain Wildan dari daerah Cianjur. Secara geografis, Kabupaten Bandung dengan Kabupaten Cianjur relatif berdekatan dengan kondisi agro-klimatologi yang relatif sama. Namun, hasil yang diperoleh pada penelitian ini relatif berbeda dengan penelitian sebelumnya. Bentuk tubuh ikan mas strain Sutisna (Kuningan) cenderung mempunyai kemiripan dengan bentuk tubuh strain Wildan (Cianjur) dan Sinyonya (Pandeglang), tetapi berbeda dengan bentuk tubuh strain Rajadanu (Kuningan) maupun Majalaya (Bandung). Beberapa alasan dapat menyebabkan terjadinya perbedaan hasil antar penelitian, antara lain: (1) Metode pembangkitan dan analisis data yang digunakan. Penggunaan metode yang berbeda cenderung menghasilkan keluaran yang berbeda. Hal ini karena sensitivitas alat, metode dan analisis yang digunakan pada masing-masing metode tersebut berbeda. (2) Metode koleksi contoh yang digunakan. Di dalam penelitian sebelumnya, contoh benih ikan mas yang digunakan diambil langsung dari daerah endemik populasi tersebut berkembang, sedangkan pada penelitian ini, benih yang digunakan berasal dari pemijahan induk yang dikoleksi oleh BRPI, Sukamandi pada tahun 2010-2012. (3) Lingkungan pemeliharaan. Induk yang digunakan untuk produksi benih dalam penelitian sebelumnya dipelihara di daerah asal masing-masing strain, sedangkan induk ikan mas hasil koleksi BRPI yang digunakan pada penelitian ini sudah dipelihara pada lingkungan yang relatif sama selama lebih dari lima tahun. Berdasarkan analisis di atas, argumentasi nomor 2 dan 3 nampaknya lebih memungkinkan terjadinya perbedaan hasil penelitin ini. Hal ini mengingat semua metode yang digunakan dalam penelitian ini mengacu pada penelitian sebelumnya, sehingga kemungkinan besar perbedaan hasil penelitian bukan disebabkan oleh faktor tersebut. Proses adaptasi yang sudah berlangsung lebih dari lima tahun diduga menyebabkan terjadinya perubahan bentuk tubuh dari masing-masing strain ikan mas. Dengan demikian, adanya variasi bentuk tubuh antar strain ikan mas dalam penelitian ini diduga lebih disebabkan karena perbedaan karakter genotipe.

\section{Karakteristik Genotipe}

Karakteristik genotipe lima strain ikan mas berdasarkan analisis mikrosatelit disajikan pada Gambar 3 dan Tabel 2. Gambar 3 menunjukkan adanya beberapa private allele pada masing-masing lokus dari setiap strain. Private allele merupakan alel yang hanya ditemukan pada satu strain dan tidak ditemukan pada strain lainnya (Syahputra et al., 2016). Sebagai contoh, alel berukuran 117 bp dan 143 bp pada lokus MFW-6 merupakan alel yang hanya ditemukan pada strain Wildan, sedangkan alel berukuran 136 bp dan 150 bp hanya ditemukan pada strain Sutisna. Pada lokus MFW7, alel berukuran 58 bp merupakan alel yang hanya ditemukan pada strain Rajadanu, alel berukuran 200, 209, 217, dan 238 bp ditemukan hanya pada strain Sutisna, sedangkan alel berukuran 266 bp hanya ditemukan pada strain Wildan. Pada lokus MFW-13 dan MFW-16, variasi alel antar strain lebih beragam dengan 

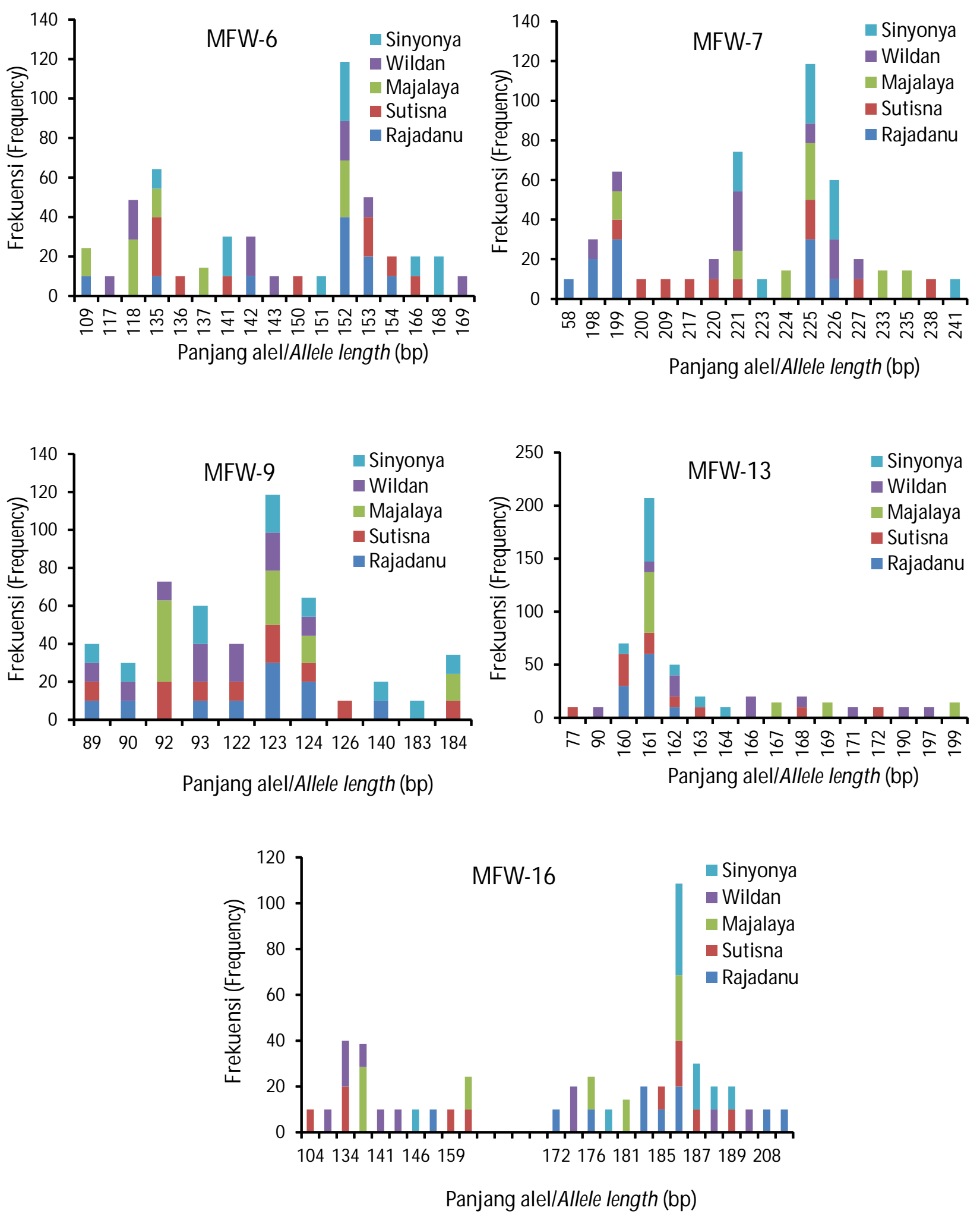

Gambar 3. Ukuran dan frekuensi alel di setiap lokus mikrosatelit pada lima strain ikan mas.

Figure 3. The allele sizes and frequencies in each microsatellite locus of five strains of common carp. 
ditemukannya beberapa privateallele pada kelima strain ikan mas. Tingginya variasi alel antar strain maupun antar individu dalam strain ikan mas menunjukkan bahwa tingkat polimorfisme marka mikrosatelit yang digunakan pada penelitian ini relatif tinggi.

Jumlah rata-rata alel setiap strain ikan mas dalam penelitian ini berbeda-beda, berkisar antara 5,8 pada strain Majalaya hingga 8,8 pada strain Wildan (Tabel 2). Rata-rata jumlah alel ini relatif sama jika dibandingkan dengan rata-rata jumlah alel yang teridentifikasi pada populasi ikan mas di Asia dan Eropa (Kohlmann et al., 2005), Bangladesh (Mondol et al., 2006), dan Vietnam (Thai et al., 2007). Frekuensi rata-rata alel pada strain Rajadanu sama dengan strain Sinyonya, mengindikasikan bahwa kedua strain tersebut mempunyai struktur genotipe yang relatif sama, tetapi berbeda dengan tiga strain lainnya. Tingkat keragaman genetik kelima strain ikan mas ditunjukkan dengan nilai diversitas gen dan heterozigositas. Dalam analisis ini, nilai diversitas gen sama dengan nilai heterozigositas harapan (expected heterozygosity/He) sedangkan nilai heterozigositas adalah nilai heterozigositas teramati (observed heterozygosity/Ho) (Nei, 1987). Strain Wildan mempunyai nilai heterozigositas $(\mathrm{Ho})$ rata-rata paling tinggi sebesar 0,20 (Tabel 2). Hasil ini mengindikasikan bahwa strain Wildan merupakan populasi plasma nutfah dengan tingkat keragaman genetik paling lebar. Namun demikian, nilai rata-rata diversitas gen $(\mathrm{He})$ strain Wildan lebih tinggi dibanding nilai heterozigositasnya (Ho). Kondisi yang samajuga terjadi pada semua strain ikan mas dalam penelitian ini, di mana nilai diversitas gen (He) lebih tinggi di atas nilai rata-rata heterozigositas (Ho). Hasil ini menunjukkan terjadinya defisit heterozigositas pada semua populasi ikan mas hasil koleksi. Dijelaskan oleh Syahputra et al. (2016) bahwa defisit heterozigositas pada suatu populasi disebabkan oleh adanya keadaan homozigot berlebihan (excess of homozygote). Munculnya keadaan homozigot berlebihan dapat disebabkan oleh fenomena null alleles, inbreeding, assortative mating, aktivitas seleksi, dan kombinasi dari beberapa faktor tersebut (Garcia de Leon et al., 1997). Homozigot berlebihan yang mengakibatkan rendahnya tingkat keragaman genetik ikan mas dalam penelitian ini diduga disebabkan aktivitas seleksi maupun fenomena inbreeding. Sebagai contoh, strain Rajadanu yang digunakan dalam penelitian ini adalah populasi yang telah mengalami seleksi selama tiga generasi di Balai Riset Pemuliaan Ikan, Sukamandi (Syahputra et al., 2015). Diduga aktivitas seleksi tersebut telah mengakibatkan hilangnya beberapa alel sehingga meningkatkan frekuensi alel-alel tertentu yang secara bersamaan menurunkan tingkat heterozigositasnya. Fenomena inbreeding pada strain-strain ikan mas didukung oleh analisis keseimbangan Hardy-Weinberg yang menunjukkan bahwa semua strain ikan mas tidak berada dalam kesimbangan $(P<0,05)$ yang baik.

Berdasarkan hasil analisis polimorfisme dan heterozigositas di atas, kelima strain ikan mas dalam penelitian ini merupakan populasi dengan tingkat homozigositas dan tingkat polimorfisme yang tinggi (homozigot heterogen). Dalam konteks ilmu pemuliaan, populasi dengan karakteristik tersebut baik untuk digunakan dalam kegiatan hibridisasi karena akan memunculkan sifat heterosis yang baik pada keturunannya. Pada kegiatan seleksi, po pulasi-populasi dengan karakteristik tersebut akan menjadi efektif jika digabungkan dalam sebuah populasi sintetis, yaitu populasi yang merupakan kombinasi dari beberapa sumberdaya genetik. Populasi sintetik umumnya mempunyai tipe yang heterozigot heterogen.

Berdasarkan hasil analisis pada Tabel 2, selanjutnya dihitung jarak genetik antar strain ikan mas. Jarak genetik antar strain ikan mas berkisar antara 0,420 yaitu antara strain Rajadanu dengan Sinyonya hingga 0,582 yaitu antara strain Majalaya dengan Sutisna (Tabel 3). Hasil penelitian ini senada dengan hasil penelitian Ariyanto et al. (2003) yang menunjukkan bahwa strain Majalaya mempunyai keragaan genotipe yang berbeda dari tiga strain ikan mas lainnya, yaitu strain Rajadanu, Sutisna, dan Wildan dengan jarak genetik sebesar 0,018 . Pada penelitian ini, penggunaan metode yang lebih teliti mampu menunjukkan perbedaan keragaan genotipe dan jarak genetik antara strain Rajadanu, Sutisna, dan Wildan dengan strain Majalaya, masingmasing sebesar 0,512; 0,582; dan 0,557 (Tabel 3).

Berdasarkan analisis jarak genetik pada Tabel 3 selanjutnya dibuat hubungan filogenetik antar strain ikan mas hasil koleksi (Gambar 4). Berdasarkan analisis filogenetik pada Gambar 4, strain Majalaya secara sendiri terpisah dari keempat strain lainnya, senada dengan hasil analisis gerombol berdasarkan bentuk tubuh (Gambar 2). Hasil ini juga sesuai dengan penelitian Ariyanto et al. (2003) yang menunjukkan bahwa strain Majalaya terpisah dengan strain Rajadanu, Sutisna, dan Wildan. Pengelompokan keempat strain lainnya dalam penelitian ini menempatkan strain Wildan terpisah dari strain Sutisna, Rajadanu, dan Sinyonya. Hasil analisis genotipe ini sedikit berbeda dengan analisis morfologi yang menempatkan strain Rajadanu terpisah dari ketiga strain lainnya (Wildan, Sutisna, dan Sinyonya). Perbedaan hasil analisis ini diduga karena adanya faktor lingkungan yang memengaruhi keragaan fenotipe ikan mas. Selain itu, lima macam lokus mikrosatelit yang digunakan dalam analisis keragaman genotipe ini bukan merupakan marka spesifik yang berhubungan dengan keragaman bentuk tubuh ikan mas. 


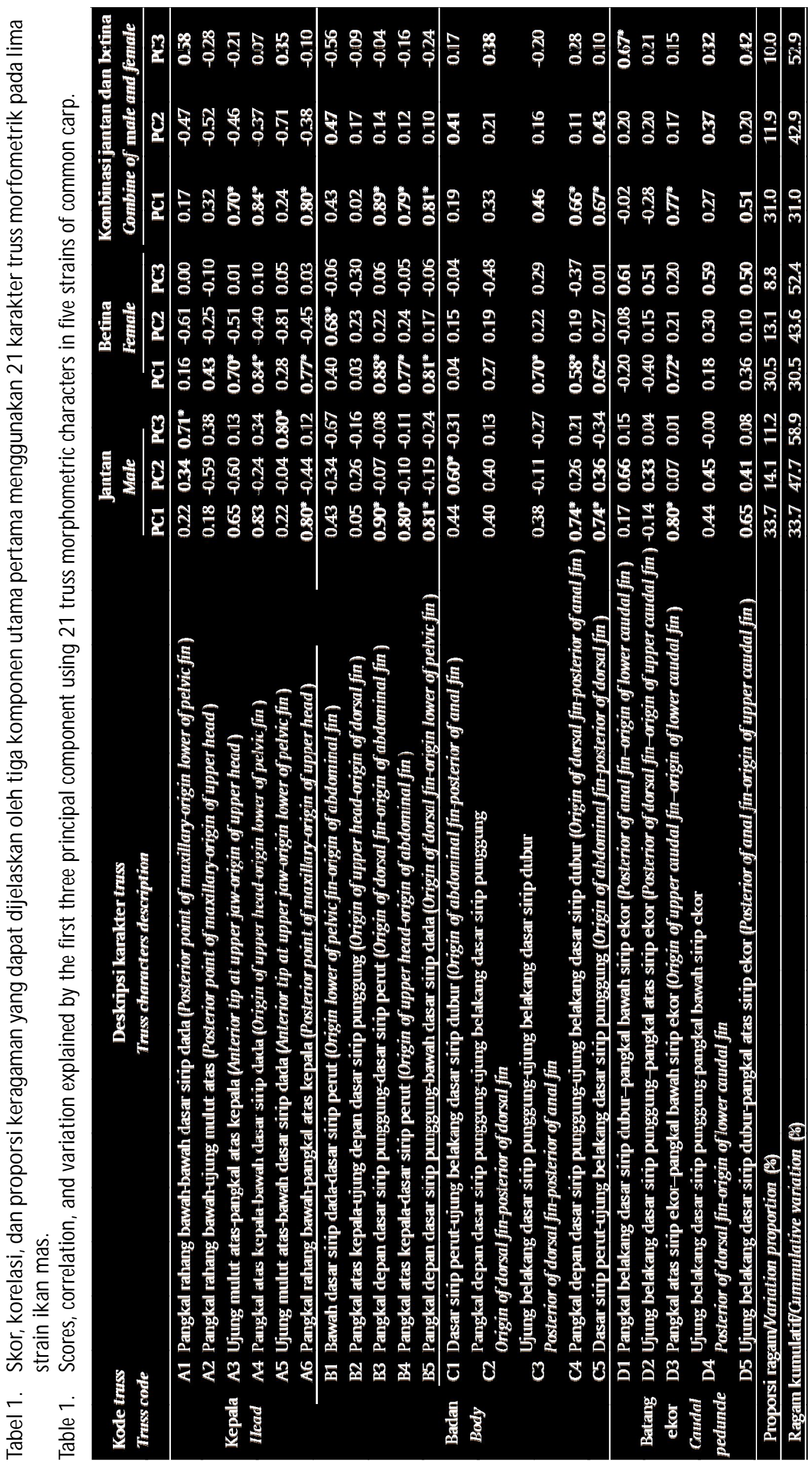

\section{罂}


Tabel 2. Hasil analisis mikrosatelit pada lima strain ikan mas Table 2. M icrosatellite analysis of five strains of common carp

\begin{tabular}{|c|c|c|c|c|c|c|}
\hline \multirow{2}{*}{$\begin{array}{l}\text { Lokus } \\
\text { Loci }\end{array}$} & \multirow{2}{*}{$\begin{array}{l}\text { Parameter } \\
\text { Param eters }\end{array}$} & \multicolumn{5}{|c|}{ Strain } \\
\hline & & Rajadanu & Sutisna & Majalaya & Wildan & Sinyonya \\
\hline \multirow{8}{*}{ MFW-6 } & Jumlah sampel (Sample number ) & 10 & 10 & 7 & 10 & 10 \\
\hline & Panjang alel (Size range of allele) & $109-154$ & $135-166$ & $109-152$ & $117-169$ & $135-168$ \\
\hline & Jumlah alel (Number of allele) & 7 & 7 & 5 & 7 & 6 \\
\hline & Frekuensi alel (Allele frequency) & 0.40 & 0.30 & 0.29 & 0.20 & 0.30 \\
\hline & Diversitas gen* (Gene diversity) & 0.77 & 0.82 & 0.78 & 0.84 & 0.80 \\
\hline & Heterozigositas** (Heterozigosity) & 0.10 & 0.00 & 0.00 & 0.00 & 0.00 \\
\hline & Polimorfisme (Polymorphism ) & 0.73 & 0.80 & 0.74 & 0.82 & 0.77 \\
\hline & $\begin{array}{l}\text { Nilai } p \text { Hardy-Weinberg } \\
\text { p value of Hardy-W einberg }\end{array}$ & 0.00 & 0.00 & 0.00 & 0.00 & 0.00 \\
\hline \multirow{8}{*}{ MFW-7 } & Jumlah sampel (Sample number ) & 10 & 10 & 7 & 10 & 10 \\
\hline & Panjang alel (Size range of allele ) & $58-226$ & $199-238$ & $199-235$ & $199-266$ & $221-241$ \\
\hline & Jumlah alel (Number of allele ) & 5 & 9 & 6 & 7 & 5 \\
\hline & Frekuensi alel (Allele frequency) & 0.30 & 0.20 & 0.29 & 0.30 & 0.30 \\
\hline & Diversitas gen (Gene diversity) & 0.75 & 0.88 & 0.82 & 0.82 & 0.76 \\
\hline & Heterozigositas (H eterozigosity) & 0.10 & 0.00 & 0.00 & 0.00 & 0.00 \\
\hline & Polimorfisme (Polymorphism) & 0.70 & 0.87 & 0.79 & 0.80 & 0.72 \\
\hline & $\begin{array}{l}\text { Nilai } p \text { Hardy-Weinberg } \\
\text { p value of Hardy-W einberg }\end{array}$ & 0.00 & 0.00 & 0.00 & 0.00 & 0.00 \\
\hline \multirow{8}{*}{ MFW-9 } & Jumlah sampel (Sample number ) & 10 & 10 & 7 & 10 & 10 \\
\hline & Panjang alel (Size range of allele ) & $89-140$ & $89-184$ & $92-184$ & $89-273$ & $89-184$ \\
\hline & Jumlah alel (Number of allele ) & 7 & 8 & 4 & 7 & 8 \\
\hline & Frekuensi alel (Allele frequency) & 0.30 & 0.20 & 0.43 & 0.20 & 0.20 \\
\hline & Diversitas gen (Gene diversity) & 0.82 & 0.86 & 0.69 & 0.84 & 0.86 \\
\hline & Heterozigositas (Heterozigosity) & 0.00 & 0.00 & 0.00 & 0.10 & 0.00 \\
\hline & Polimorfisme (Polymorphism) & 0.80 & 0.84 & 0.64 & 0.81 & 0.84 \\
\hline & $\begin{array}{l}\text { Nilai } p \text { Hardy-Weinberg } \\
\text { p value of Hardy-W einberg }\end{array}$ & 0.00 & 0.00 & 0.00 & 0.00 & 0.00 \\
\hline \multirow{8}{*}{ MFW-13 } & Jumlah sampel (Sample number ) & 10 & 10 & 7 & 10 & 10 \\
\hline & Panjang alel (Size range of allele) & $160-197$ & $77-208$ & $161-210$ & $90-209$ & $160-198$ \\
\hline & Jumlah alel (Number of allele) & 4 & 9 & 7 & 12 & 6 \\
\hline & Frekuensi alel (Allele frequency) & 0.45 & 0.25 & 0.50 & 0.20 & 0.45 \\
\hline & Diversitas gen (Gene diversity) & 0.68 & 0.86 & 0.70 & 0.88 & 0.73 \\
\hline & Heterozigositas (Heterozigosity) & 0.30 & 0.30 & 0.43 & 0.50 & 0.30 \\
\hline & Polimorfisme (Polymorphism ) & 0.62 & 0.84 & 0.68 & 0.87 & 0.70 \\
\hline & $\begin{array}{l}\text { Nilai } p \text { Hardy-Weinberg } \\
\text { p value of Hardy-W einberg }\end{array}$ & 0.00 & 0.00 & 0.01 & 0.00 & 0.01 \\
\hline \multirow{8}{*}{ MFW-16 } & Jumlah sampel (Sample number ) & 10 & 10 & 7 & 10 & 10 \\
\hline & Panjang alel (Size range of allele) & $158-240$ & $104-192$ & $138-188$ & $133-197$ & $146-190$ \\
\hline & Jumlah alel (Number of allele) & 7 & 9 & 7 & 11 & 8 \\
\hline & Frekuensi alel (Allele frequency) & 0.20 & 0.20 & 0.29 & 0.20 & 0.40 \\
\hline & Diversitas gen (Gene diversity) & 0.84 & 0.87 & 0.82 & 0.89 & 0.77 \\
\hline & Heterozigositas (Heterozigosity) & 0.00 & 0.10 & 0.29 & 0.40 & 0.20 \\
\hline & Polimorfisme (Polymorphism ) & 0.82 & 0.85 & 0.79 & 0.88 & 0.75 \\
\hline & $\begin{array}{l}\text { Nilai p Hardy-Weinberg } \\
\text { p value of Hardy-W einberg }\end{array}$ & 0.00 & 0.00 & 0.00 & 0.00 & 0.00 \\
\hline
\end{tabular}


Tabel 2. Lanjutan

Table 2. Continued

\begin{tabular}{clccccc}
\hline \multirow{2}{*}{$\begin{array}{c}\text { Lokus } \\
\text { Loci }\end{array}$} & \multicolumn{1}{c}{$\begin{array}{c}\text { Parameter } \\
\text { Parameters }\end{array}$} & \multicolumn{5}{c}{ Strain } \\
\cline { 3 - 7 } & & Rajadanu & Sutisna & Majalaya & Wildan & Sinyonya \\
\hline \multirow{3}{*}{ Rata-rata } & Jumlah alel (Number of allele) & 6.00 & 8.40 & 5.80 & 8.80 & 6.60 \\
Mean & Frekuensi alel (Allele frequency) & 0.33 & 0.23 & 0.36 & 0.22 & 0.33 \\
& Diversitas gen (Gene diversity) & 0.77 & 0.86 & 0.76 & 0.85 & 0.78 \\
& Heterozigositas (Heterozigosity) & 0.10 & 0.08 & 0.14 & 0.20 & 0.10 \\
& Polimorfisme (Polymorphism) & 0.74 & 0.84 & 0.73 & 0.84 & 0.76 \\
\hline
\end{tabular}

Keterangan (Note): *Diversitas gen $=$ heterozigositas harapan $(\mathrm{He}) .{ }^{*}$ Heterozigositas= heterozigositas teramati $(\mathrm{Ho})$ (Nei, 1987).

Tabel 3. Jarak genetik antar lima strain ikan mas hasil koleksi berdasarkan analisis mikrosatelit

Table 3. Genetic distance among five strains of common carp based on microsatellite analysis

\begin{tabular}{lccccc}
\hline \multicolumn{1}{c}{ Strain } & Majalaya & Rajadanu & Sinyonya & Sutisna & Wildan \\
\hline Majalaya & $* * *$ & & & & \\
Rajadanu & 0.512 & $* * *$ & & & \\
Sinyonya & 0.538 & 0.420 & $* * * *$ & & \\
Sutisna & 0.582 & 0.489 & 0.452 & $* * *$ & \\
Wildan & 0.557 & 0.513 & 0.541 & 0.510 & $* * *$ \\
\hline
\end{tabular}
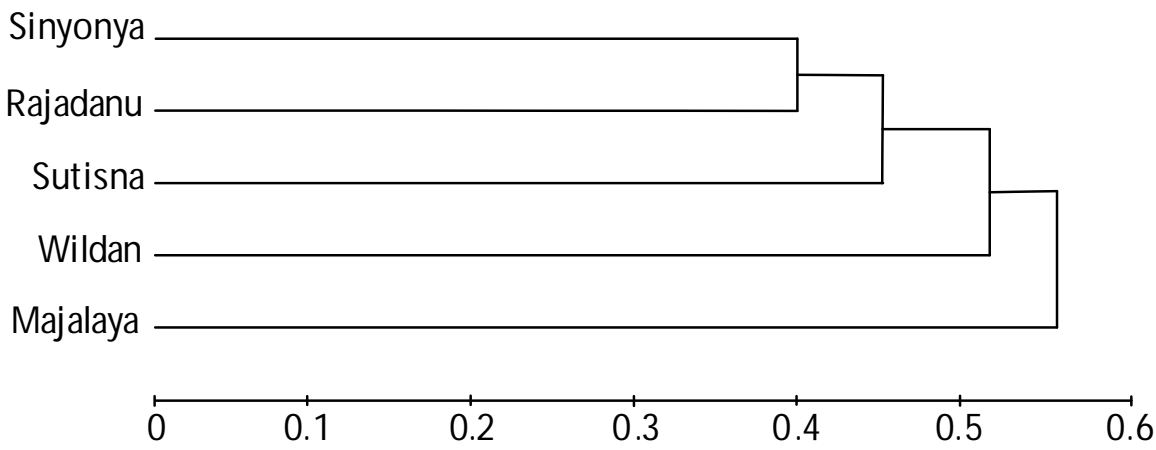

Gambar 4. Dendrogam jarak genetik antar lima strain ikan mas berdasarkan hasil analisis mikrosatelit menggunakan lima lokus pada Tabel 2.

Figure 4. Dendrogram of the genetic distance among five strains of common carp based on microsatellite analysis.

\section{KESIMPULAN DAN SARAN}

Keragaman fenotipe lima strain ikan mas di Jawa Barat dan Banten sesuai dengan keragaman genotipenya. Secara umum, keragaman genotipe strain-strain tersebut relatif rendah, dengan nilai heterozigositas kurang dari 0,20. Namun demikian, tingkat polimorfisme kelima strain ikan mas tersebut relatif tinggi, berkisar antara 0,73-0,84 dan jarak genetik antar strain yang relatif jauh, berkisar antara 0,420 (Rajadanu dengan Sinyonya) hingga 0,582 (Majalaya dengan Sutisna).

Pemuliaan ikan mas dapat dilakukan melalui program hibridisasi karena jarak genetik yang relatif jauh antar strain. Pada kegiatan jangka panjang, pemuliaan 
ikan mas dapat dilakukan melalui program seleksi yang diawali dengan pembentukan populasi sintetis sebagai populasi dasar bahan seleksi.

\section{UCAPAN TERIMA KASIH}

Penelitian ini dibiaya oleh APBN melalui DIPA No. 032.11.2.660052/2016 di Balai Riset Pemuliaan Ikan, Sukamandi tahun 2016. Penulis menyampaikan terima kasih kepada teknisi lapangan dan laboratorium, serta kepada Dewan Redaksi Jurnal Riset Akuakultur dalam perbaikan makalah ini.

\section{DAFTAR ACUAN}

Ariyanto, D., Nugroho, E., \& Subagyo. (2003). Karakterisasi biokimia enzimatis 4 strain ikan mas: Majalaya, Rajadanu, Wildan dan Sutisna. Jurnal Penelitian Perikanan Indonesia, 9(4), 1-6.

Edge, T.A., McAllister, D.E., \& Qadri, S.U. (1991). Meristic and morphometric variation between the endangered Acadian whitefish, Coregonus hutsmani and the lake whitefish, Coregonus clupeaformis, in the Canadian maritime provinces and the State of Maine, USA. Can. J. Fish. Aquat. Sci., 48(11), 21402151.

Garcia de Leon, F.J., Chikhi, L., \& Bonhomme, F. (1997). Microsatellite polymorphism and population subdivisionin natural population of European sea bass (Dicentrarchus labrax Linnaeus 1758). M olecular Ecology, 6(1), 51-62.

Hardjamulia, A., Asih, S., Supriyadi, H., \& Muharam, B. (1996). Karakterisasi morfologis dan evaluasi beberapa plasma nutfah ikan mas (Cyprinus carpio). Bulletin Plasma Nutfah, II(1), 24-28.

Herbinger, C.M., Doyle, R.W., Pitman, E.R., Paquet, D., Mesa, K.A., Morris, D.B., Wright, J.M., \& Cook, D. (1995). DNA fingerprint-based analysis of paternal and maternal effect on offspring growth and survival on communally reared rainbow trout. Aquaculture, 137, 245-256.

Hulak, M., Kaspar, V., Kohlmann, K., Coward, K., Tešitel, J., Rodina, M., Gela, D., Kocour, M., \& Linhart, O. (2010). Microsatellite-based genetic diversity and differentiation of foreign common carp (Cyprinus carpio) strains farmed in the Czech Republic. Aquaculture, 298, 194-201.

Imron, Subagyo, \& Arifin, 0.Z. (2000). Keragaman truss morfometrik 4 strain ikan mas: Majalaya, Rajadanu, Wildan, dan Sutisna. Prosiding Penelitian Perikanan 1999. Puslitbang Perikanan. Departemen Kelautan dan Perikanan, hlm. 188-197.

Jayasankar, P., Thomas, P.C., Paulton, M.P., \& Mathew, J. (2004). Morphometric and genetic analyzes of
Indian mackerel (Rastrelliger kanagurta) from Peninsular India. Asian Fisheries Science, 17, 201-215.

Kohlmann, K., Kersten, P.T., \& Flajshans, M. (2005). Microsatellite-based genetic variability and differentiation of domesticated, wild and feral commoncarp (Cyprinus carpio L.) populations. Aquaculture, 247, 253-266.

Matricia, T. (1990). Morphological and growth variability among common carp population in different geographical areas in Indonesia. M.Sc. Thesis. Dalhousie Univ., Halifax, NS, Canada, 153 pp.

Mondol, K.R., Islam, S., \& Alam, S. (2006). Characterization of different strains of common carp (Cyprinus carpio L.) (Cyprinidae, Cypriniformes) in Bangladesh using microsatellite DNA markers. Genetics and Molecular Biology, 29(4), 626-633.

Nei, M. (1987). Genetic distance and molecular phylogeny. In Ryman \& Utter, F. (Eds). Populations Genetics and Fishery Management. Seattle, WA: University of Washington Press, p. 193-223.

Ninh, N.H., Ponzoni, R.W., Nguyen, N.H., Woolliams, J.A., Taggart, J.B., McAndrew, B.J., \& Penman, D.J. (2011). A comparison of communal and separate rearing of families in selective breeding of common carp (Cyprinus carpio): Estimation of genetic parameters. Aquaculture, 322-323, 39-46.

Nugroho, E., Wahyudi, N.A., \& Sudarto. (1991). Penentuan jenis kelamin ikan mas dengan membandingkan bentuk tubuh melalui tehnik "truss morphometrics". Bulletin Penelitian Perikanan Darat, 10(1), 23-29.

Romana-Eguia, M.R.R., Ikeda, M., Basiao, Z.U., \& Taniguchi, N. (2004). Genetic diversity in farmed Asian nile and red hybrid tilapia stocks evaluated from microsatellite and mitochondrial DNA analysis. Aquaculture, 236, 131-150.

Rukmono, D. (2005). Kebijakan pengelolaan kesehatan ikan direktorat kesehatan ikan dan lingkungan. Dalam Supriyadi, H., \& Priono, B. (Eds.). Strategi Pengelolaan dan Pengendalian Penyakit KHV. Jakarta: Pusat Riset Perikanan Budidaya, hlm. 1-6.

Strauss, R.E. \& Bond, C.E. (1990). Taxonomic methods: Morphology. Methods for Fish Biology. American Fiheries Society, Bethesda, Maryland, USA, p. 109-140.

Subagyo, Muharom, B., Arifin, O.Z., \& Asih, S. (2000). Perbaikan mutu benih ikan mas melalui pendekatan genetik, nutrisi, dan lingkungan. Laporan Balai Penelitian Perikanan Air Tawar. T.A. 1999/2000, 15 hlm.

Swain, D.P., Riddell, B.E., \& Murray, C.B. (1991). Morphological differences between hatchery and wild 
populations of Coho salmon, Oncorhynchus kisutch: environmental versus genetic origin. Can. J. Fish. Aquat. Sci., 48(9), 1783-1791.

Syahputra, K., Ariyanto, D., \& Hayuningtyas, E.P. (2016). Keragaman genetik ikan mas (Cyprinus carpio) varietas Rajadanu tahan Koi Herpesvirus generasi F-0 dan F-1 menggunakan tiga lokus mikrosatelit. Jurnal Riset Akuakultur, 11(1), 59-66.

Takezaki, N., \& Nei, M. (1996). Genetic distance and reconstruction of phylogenic trees from microsatellite DNA. Genet., 144, 389-399.

Thai, B.T., Burridge, C.P., \& Austin, C.M. (2007). Genetic diversity of common carp (Cyprinus carpio L.) in Vietnam using four microsatellite loci. Aquaculture, 269, 174-186.
Velasco, R.R., Pante, M.J.R., Macaranas, J.M., Janagap, C.C., \& Eknath, A.E. (1996). Truss morphometric characterization of eight strain of nile tilapia (Oreochromis niloticus). In Pullin, R.S.V., Lazard, J., Legendre, M., Kothias, J.B.A., \& Pauly, D. (Eds.).

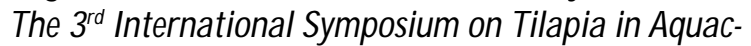
ulture. ICLARM Conf. Proc., 41, 415-425.

Wang, C. \& Li, S. (2007). Genetic effects and genotype $x$ environment interactions for growth-related traits in common carp, Cyprinus carpio L. Aquaculture, 272, 267-272.

Yue, G.H., Ho, M.Y., Orban, L., \& Komen, J. (2004). Microsatellites within genes and ESTs of common carp and their applicability in silver crucian carp. Aquaculture. 234, 85-98. 